ウォーターセットを利用した毛髪の新規ストレートパーマ施術法

\author{
上甲 恭平 ${ }^{\#}$ 山本 奈絵子
}

\title{
A New Permanent Straightening Process of Human Hair Using the Water Set
}

\author{
Kyohei Joko" and Naeko Yamamoto
}

Department of Human Environment Design, Sugiyama Jogakuen University, 17-3, Hoshigaoka-motomachi, Chikusa-ku, Nagoya, Aichi 464-8662, Japan

\begin{abstract}
The straightening hair style can also be formed by only the hot ironing process although relies on the actions of heat and moisture. We conducted a new straightening process based on the assumption that if the distortion of some disulfide bonds generated in the process of straightening the hair tress is removed, straightening style is retained permanently. The new straightening process which we have proposed is as follows : (1) shampoo a small hair tress (30 $\mathrm{cm}),(2)$ remove excess water from hair tress with a towel, (3) run through a flat iron along hair tress at $175^{\circ} \mathrm{C}$ for $15 \mathrm{sec}$ and repeat this process two times, (4) apply a commercial straightening cream containing ammonium thioglycolate at $30^{\circ} \mathrm{C}$ for $2 \mathrm{~min}$, (5) rinse sufficiently with tap water, and (6) oxidize with a commercial neutralization cream containing hydrogen peroxide at $30^{\circ} \mathrm{C}$ for $2 \mathrm{~min}$. As a result, it was verified that the straightening of wavy hair could be achieved permanently by the proposed straightening process, as was confirmed by the phenomenon that the straightening hair tress was more resistant to immersion in boiling water for $30 \mathrm{sec}$. We believe that the proposal straightening process is of the effective process that may achieve permanent hair straightening. It should be noted that the most important factor in this process is that the non-keratin protein chain of cortical cell layer repositioned so as to eliminate the distortion of the internal structure caused by ironing treatment. It has been suggested, furthermore, that the cleavage of the distorted disulfide bonds in cuticle cells serves to remove the strain forces localized to the fiber surface area and simultaneously lead to results that stabilize hair style in straight.
\end{abstract}

(Received 10 June, 2014 ; Accepted 30 September, 2014)

\section{1. 緒 言}

毛髪のパーマネントセット形成機構については古くか ら議論され,「コルテックス細胞を構成する中間径フィラ メント $(\mathrm{IF}) /$ 中間径フィラメント結合タンパク (IFAP) 複合 組織内のジスルフィド(-SS-)結合が還元剤により切断(還 元)され, その切断に伴い IF が新たな位置に再配向 (構造 的再配列) し, 酸化剂により IF/IFAP 複合組織内での-SS結合を再結合(酸化)させることでパーマネントウェーブ を形成する」との考えが広く受け入れられている。この 理論は還元剤との反応による-SS-結合の切断/再結合を ベースとしたものである. したがって, 現在ではウェー ブパーマであれストレートパーマであれ，まずは，毛髪 内の-SS-結合を十分に切断する施術法(従来法)が基本と なっている $[1]$. 本研究で取り上げたストレートパーマで は，毛髪を還元剤で十分に軟化するまで還元し，その後， 水洗し乾燥させた後にアイロンによりストレートとして

\# corresponding author

* 椙山女学園大学
いる.このような方法では, 還元後の熱処理が条件によっ て内部構造を大きく変性させるため, 水分量などの条件 を厳しくコントロールすることが要求される [2].

ところで, ウェーブの形成やその安定性については, 古くから-SS-結合だけでなく水素結合やイオン結合などの 二次結合が重要な働きをしているとの主張もある [3]. し かし, 現在では, ほとんど議論されることがない. とこ ろが, 最近, 我々はパーマネントウェーブでのウェーブ 形成には，還元剤の反応がおよんでいない非還元部位の 歪の緩和が重要な役割を果たしていることを見出した[46]. この歪緩和には構造的再配列を伴うが, それには水 素結合やイオン結合などの二次結合の切断/再結合が深く 関与している. このことから, 我々は水素結合やイオン 結合などの二次結合の切断にともなう構造的再配列と再 結合による構造の固定化が, セット形状形成機構の重要 な役割を果たしているとの考えを強くしている.

この考えは, 家庭において日常ホットカーラーによる ウェーブセットや熱アイロンによるストレート処理が行 われているように, -SS-結合を切断することなく容易に毛 髪の形状を変えていることからも支持される.この現象 
は一次セット(ウォーターセット)として, 水素結合の切 断/再結合にともなう構造的再配列によるものであること はよく知られている $[7]$. しかし, 一次セット現象は, 水 素結合によるものであるため, 水分が与えられると容易 に元の形状に戻りパーマネント性はない.

我々は, この一次セット挙動に着目し, あらかじめ所 望の形状に一次セットしておいた毛髪の復元力 (元の形状 に戻ろうとする力) となる内部歪を, 形状を維持したまま 除くことができれば，七ットした形状が維持できるだけ でなく, 従来法と比べ毛髪の損傷も大幅に軽減できると の考えに基づき検討を行ってきた. その結果, この考え に基づく施術法(新規法)によってもパーマネントセット (ウェーブパーマ, ストレートパーマ)が可能であること を見出した。本報告では, 熱アイロンによるストレート パーマを取り上げ, パーマネントセットとするための処 理条件やその作用・効果について検討したので, その結 果について報告する。

\section{2. 実 験}

\section{1 試料および試薬}

毛髪試料として, 化学的処理が施されていない中国人 女性 2 名 (以下, 毛束 A, 毛束 B と記す)のウェーブ毛髪 $(30 \mathrm{~cm})$ をカーリングインターナショナル社より購入し, $1 \%$ ラウリル硫酸ナトリウム (エデト酸二ナトリウム $0.1 \%$ 含有)で洗浄精製したものを使用した。試料毛束は毛髪 40 本 $(0.07 \sim 0.09 \mathrm{~g})$ を束ねて作製した. パーマネント処理に 用いた薬剤として, 還元剤には市販品であるリシオグラ ンフェ VD-H[ミルボン(株) : クリーム I 剤 (還元剤 : チオ グリコール酸アンモニウム)]を, 酸化剤にはリシオグラ ンフェ VK-N[ミルボン(株) : クリームII剂(酸化剂 : 過酸 化水素) ]を用いた. SH 基修飾剂には $N$-[7-dimethyl-amino -4-methyl-coumarinyl $]$ maleimide (DACM)の試薬特級品を使 用した。

\section{2 アイロン処理}

施術用アイロンには業務用アイロンを用いた。アイロ ン処理は, まず, 予め毛髪を十分に湿潤させた後, 余分 な水分をタオルで除いた後, 毛束接地面温度を所定温度 に設定したアイロンを毛束の根本から毛先方向に滑らす ように一定の圧力で 15 秒かけて処理する方法で行った. この処理を 2 回繰り返した。

\section{3 還元・酸化処理}

アイロンストレート処理毛束の還元酸化処理は, 通常 のストレートパーマネント処理法に準じ, 毛束 1 本に対 して約 $1 \mathrm{~g}$ のクリーム I 剂を毛束全体に揉みこむように塗 布し, $30^{\circ} \mathrm{C}$ に設定した自然対流型乾燥機に所定時間放置 した後, 水道水で十分に水洗した. その後, クリーム II 剂約 $1 \mathrm{~g}$ を均一に塗布し 2 分間放置した後, 水道水で十分 に水洗した。毛束の乾燥は自然乾燥あるいは接地面温度 を $150^{\circ} \mathrm{C}$ に設定したアイロンで滑らすようにして乾燥させ
た。

\section{4 蛍光顕微鏡観察}

毛髪の還元域の観察は, S. Ogawa ら [8]の方法に準じた 予備実験の結果, 以下に示す方法で行った。 ストレート 処理毛髪に還元用クリームを所定量塗布して2 分間放置 した後, 窒素置換した蒸留水で十分に水洗した毛髪を,

$0.1 \mathrm{mmol} / \mathrm{L} \mathrm{DACM}$ トリス緩衝溶液に 60 分間浸漬処理した。 処理後直ちに処理試料を蒸留水で十分に水洗しペーパー タオルで余分な水分を除いた. その後, ミクロトームを 用いて処理毛髪から厚さ $5 \mu \mathrm{m}$ の切片を切り出し, その切 片の蛍光像を蛍光顕微鏡 (ニコン社製 ECLIPSE E600POL) を用いて $360 \mathrm{~nm}$ の励起光にて観察し, デジタルマイクロ スコープ(キーエンス社製)により撮影した。

\section{5 示差走査熱量測定 (DSC)}

新規法(熱アイロン/還元/酸化)にて処理した毛髪を粉末 状に裁断した後, その粉末状試料を約 $2 \mathrm{mg}$ を精秤し, 開 放アルミパンに封入して測定試料とした. 常圧 DSC 測定 は高圧示差走査熱量計 DSCQ10(TA instruments 社製)を用 い, 測定用圧力七ルを常圧に調整後, 流速 $50 \mathrm{~mL} / \mathrm{min}$ で窒 素ガスを流しながら昇温速度 $20^{\circ} \mathrm{C} / \mathrm{min}$, 室温〜 $280^{\circ} \mathrm{C}$ の温 度範囲で行った。

\section{3. 結果と考察}

\section{1 一次セット}

ウェーブ毛髪 (毛束A)が熱アイロン $\left(175^{\circ} \mathrm{C}, 15\right.$ 秒間 2 回処理)によりストレートにセットされ, 水浸漬で元の ウェーブ形状に戻る様子を図 1 に示した。 図から明らか なように, このウェーブ毛髪は還元処理を施さなくても ストレートになることがわかる. しかし, 水中に浸漬す るとほぼ元の形状に戻る.この現象は, 以下のように解 釈することができる：

熱アイロン処理によりストレート形状に再配列した分

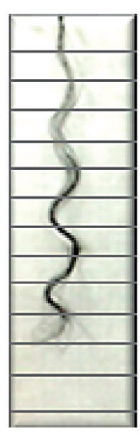

(A)

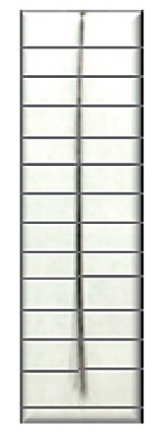

(B)

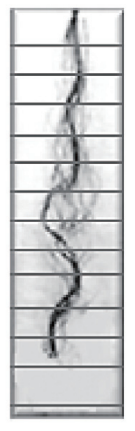

(C)
Fig. 1 Photographs of the tress shape of (A) the original wavy hair, (B) the hair straightened using hot iron, and (C) the straightening hair immersed in cold water.

(Ironing condition : processing temp. ; $175^{\circ} \mathrm{C}$, processing time; $15 \mathrm{sec}$ throughout the whole tress, processing count; 2 times.). 
子鎖の一部は, 二次結合の再結合により安定状態にある が，水分および熱により切断できない-SS-結合やイソペプ チド結合の一次結合は歪んだ状態にある。 ストレート状 態にセットされ形状を保っていることは, 二次結合の総 力による形状保持力が歪んだ一次結合の復元応力に勝っ ているためである.しかし, 湿潤状態となると吸着水分 により二次結合が切断されるため, 復元応力とのバラン スが崩れその応力を緩和するために分子鎖が移動再配列 してょり安定な元の形状に戻ることとなる.

\section{2 一次セット毛髮の歪除去効果}

\subsection{1 還元処理による歪除去効果}

一次セット状態での内部歪の主因子である-SS-結合の切 断による歪除去を目的として，市販クリームI剂による 還元処理時間とその効果について検討した. 図 2 は, 試 料に毛束 $\mathrm{A}$ を用い熱アイロン $\left(175^{\circ} \mathrm{C}, 15\right.$ 秒間 2 回処理 $)$ により一次セット後, 所定時間還元処理した毛髪の湿潤 状態と乾燥状態での毛束の写真である.

まず, 還元処理後の湿潤状態での毛束形状から, 若干 ウェーブが戻るようであるが, 還元 5 秒においてもほぼ 一次セット状態が保持されることがわかる. しかし, 乾 燥させた状態では, 還元 2 分処理を除いて元の状態とま では戻らないもののウェーブの強い毛束に戻っている. このことから, 歪んだ-SS-結合には, 水膨潤時に復元応力 を発現する-SS-結合と, 乾燥 (脱膨潤)時の分子再配列の際 に復元応力を発現する-SS-結合が存在していることが示唆 される. 前者の-SS-結合が, 還元剤が塗布されると瞬時に 切断されることから, 還元剤からの電子の移動により還 元切断されると考えられるのに対して, 後者の-SS-結合は,
その切断が還元処理時間に依存することから, 繊維内部 に浸透拡散した還元剂と直接反応することで還元切断さ れるものと考えられる.

以上のことから, ウェーブ毛髮をストレートにパーマ ネントセット(ストレートパーマ)する方法として, 一次 セット後に歪んだ-SS-結合を切断する方法でも湿潤耐性 (パーマネント性)のあるセットが可能であることがわか る.ただし, ストレートパーマとするには, 乾燥時に復 元応力として働く-SS-結合を必要最小限切断することが必 要となる.

\subsection{2 還元剤の浸透域}

図 2 の結果では, ストレートパーマは還元 2 分処理に よって得られたので, 2 分処理によって還元される部位に ついて, アイロン処理 (一次セット)した後, 還元 2 分処 理により生成した-SH 基を蛍光剂 DACM でラベル化を行 い蛍光顕微鏡により観察することで調べた. 図 3 の写真 がその毛髪断面の自家蛍光除去処理を施した顕微鏡写真 である.

この写真からは, 毛髪表面層に強い蛍光が認められる. 一般に, 正常な毛髪では毛髪の長径に対するキューティ クル細胞層の比率は約 0.07 でるとされている [9]. この 写真の発光部分の厚さと直径との比率を求めると 0.04 0.55 となることから, 発光部分はほぼキューティクル細 胞であると考えられる. また, 観察結果は省いたが還元 5 分処理毛髪断面ではコルテックス細胞に発光が認められ たことからも，還元 2 分処理では主にキューティクル細 胞層の-SS-結合が還元されていることを確認している.と ころで, 前項でアイロンによるストレート処理によって

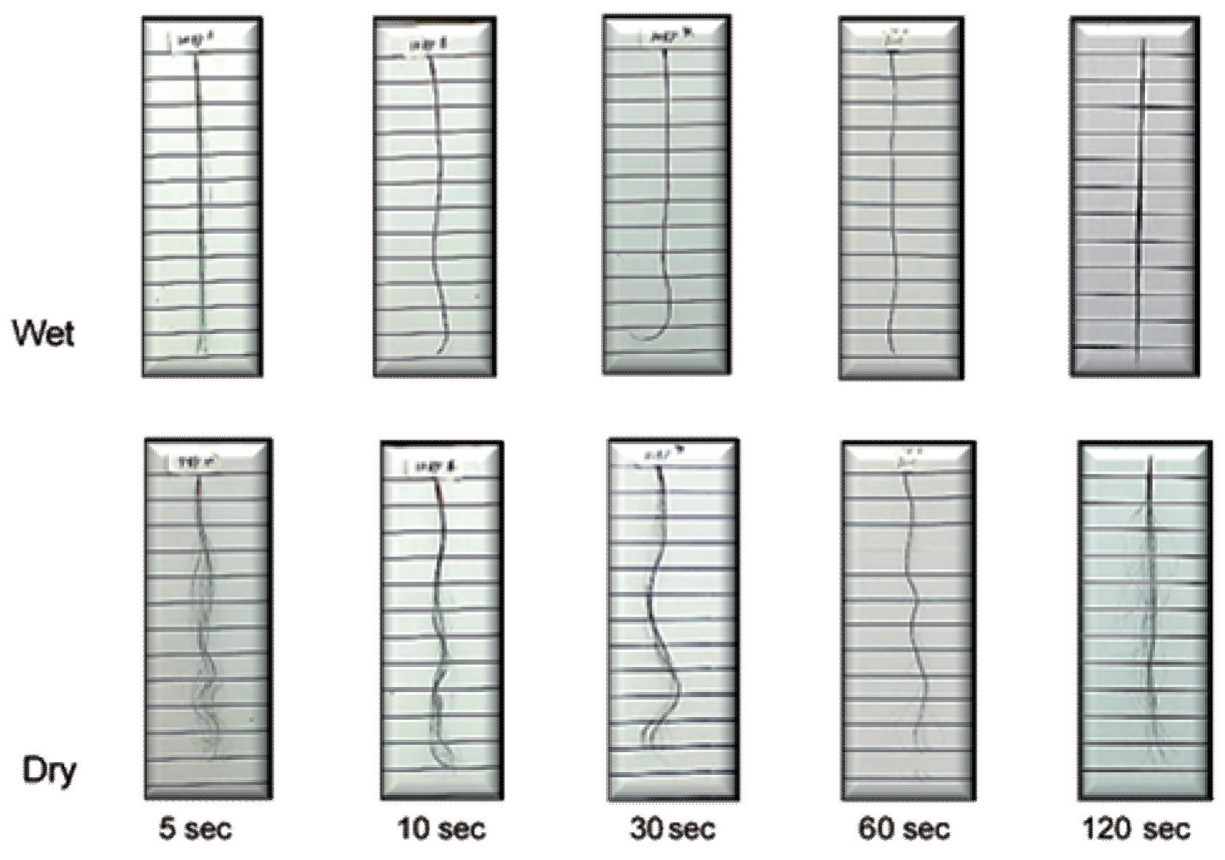

Fig. 2 Effects of the operating time of reducing processing on the straightening performance of the wet and dry hair tress, which was reduced in the commercial reduction cream formulation after the ironing straightening treatment.

(Ironing condition : processing time ; $15 \mathrm{sec}$ throughout the whole tress, processing count ; 2 times.) 


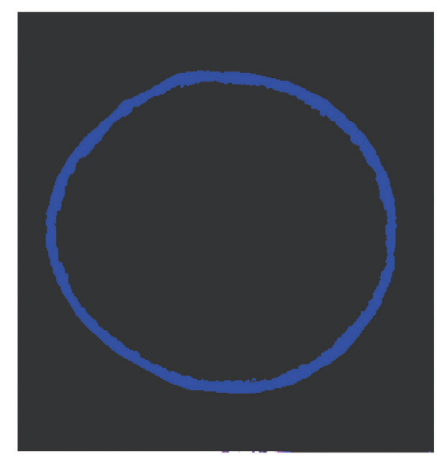

Fig. 3 Fluorescence micrograph of the cross section of the reduced hair labeled by the DACM. (Reduction treatment time is 2 minutes).

歪む-SS-結合には，水膨潤時に復元応力を発現する-SS-結 合と, 乾燥時に復元応力を発現する-SS-結合が存在すると 述べたが．歪を持つ主な-SS-結合はこの写真で観察された 還元部位に存在すると考えることができる.

以上のことから，乾燥後にストレート形状を保持する ために切断する必要のある-SS-結合は，キューティクル細 胞特に-SS-結合含有量が多いエキソキューティクル域のSS-結合であり, コルテックス細胞内の-SS-結合の切断は 不要であると言うことができる.

\section{3 一次セット時のアイロン温度}

次に，一次セット/還元処理後のセット形状に扮よほすす 一次セット用アイロンの接地面温度の影響について調べ た.

図 4 は, 試料に毛束 $\mathrm{B}$ を用い, アイロンの接地面温度
Wet

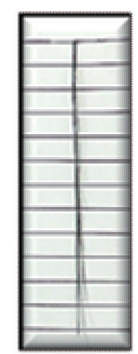

Dry

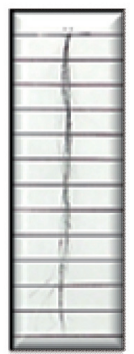

$175^{\circ} \mathrm{C}$
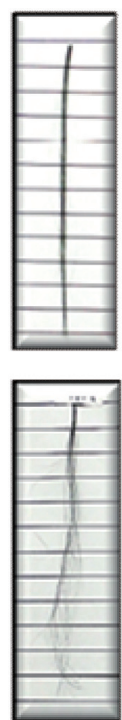

$165^{\circ} \mathrm{C}$
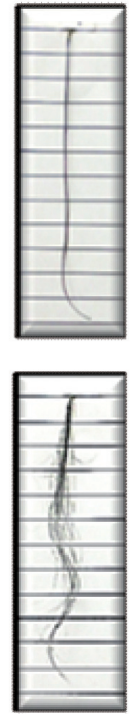

$155^{\circ} \mathrm{C}$
Fig. 4 Effects of the operating temperature of ironing on the straightening performance of the wet and dry hair tress, which was reduced in the commercial reduction cream formulation after the ironing straightening treatment.

(Ironing condition: processing time; $15 \mathrm{sec}$ throughout the whole tress, processing count ; 2 times.)
を $155^{\circ} \mathrm{C}, 165^{\circ} \mathrm{C}, 175^{\circ} \mathrm{C}$ (15 秒間 2 回处理)で一次セット した後， 2 分間還元処理した場合の湿潤状態と乾燥状態で の毛束写真を示したものである.

この図から明らかなように，還元後湿潤した状態では， アイロン処理温度にかかわらずストレート形状を保って いるが, 乾燥させると $175^{\circ} \mathrm{C}$ よりも低い温度ではウェー ブ状に戻っていることがわかる。この結果であるが，ま ず， $175^{\circ} \mathrm{C}$ 处理毛束でほぼストレートにセットされている ことから，還元処理によりキューティクル細胞内の歪ん だ-SS-結合の必要量が切断されていると考えられる。故に， $150^{\circ} \mathrm{C}$ 処理毛束においても同様に切断されていると考えら れる。したがって, $150^{\circ} \mathrm{C}$ 処理毛束でストレート形状が維 持されなかった原因が還元不足とは考え難く，この原因 はストレート処理時の外力により生じた構成分子鎖の歪 が十分に緩和されていないことにあると考えられる。す なわち，アイロン処理時に二次結合がかかわる構成分子 鎖の歪が十分に緩和されている必要があることを示して おり, $150^{\circ} \mathrm{C}$ 処理での熱エネルギーは内部構成分子鎖の再 配列をスムーズに行わせるにはエネルギー不足であるこ とを示すものである

\section{4 酸化による-SS-再結合の影響}

続いて，ストレートセット性に抢よぼす-SS-結合の再結 合の影響と酸化・乾燥処理を含めた一連の施術により得 られた毛束のパーマネント性について検討した．図 5 に その結果を示す．図 5(A) は図 2 と同様の方法でアイロン. 還元 (2 分間) 処理し水洗した後, 市販クリーム状酸化剂に て2 分処理し, 水洗, 自然乾燥させた毛束の写真である. (B) は乾燥を $150^{\circ} \mathrm{C}$ に設定した熱アイロンで乾燥させたも のの写真で, (C) は (B)の毛束を煮沸水中で 30 秒間浸漬処 理した後, 乾燥させた毛髪の形状写真である。

まず，(A)の形状は還元処理後乾燥させた形状と変わっ

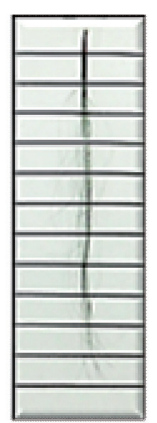

(A)

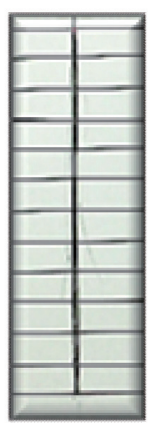

(B)

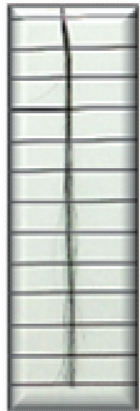

(C)
Fig. 5 Photographs of the hair tress operated (A) reduction/oxidation/air drying processing, and (B) reduction/oxidation/hot iron drying processing, and (C) boiled with water after the reduction/oxidation/hot iron drying.

(Oxidation condition: neutralizing agent; commercial neutralization cream, temp. ; $30^{\circ} \mathrm{C}$, time; 2 min. Iron drying condition: temp; $150^{\circ} \mathrm{C}$, time ; in very fast motion, processing count ; 2 times.) 
ていないことから，還元により切断された-SS-結合の再結 合は毛髪形状には影響をおよぼさないことがわかる。ま た，(B)に示したアイロン乾燥は自然乾燥より毛束のスト レート性が保持されていることがわかる.このことから 自然乾燥中でも毛髪内部の微小域において構成分子鎖の 再配列が起こっているのに対して，アイロン乾燥では乾 燥スピードが速く再配列が抑制されていると考えられる。 このことは $(\mathrm{C})$ に示した煮沸処理毛束の形状が $(\mathrm{A})$ の毛束 形状より整っていることからも支持される.ささらに, 者 沸処理後の毛束がストレート状を保っていることから, この一連の施術法によってウェーブ毛髮をパーマネント 性に優れたストレート状毛髮にセットできることが確認 できた。

\section{5 コルテックス細胞への影響}

上述したように，還元 2 分処理による作用域はキュー ティクル細胞層であったが, 酸化処理までの一連の処理 によるコルテックス細胞への影響について常圧 DSC 測定 より求めた $\alpha$-結晶の変性挙動より検討した. 図 6 に, 図 5 と同様に熱アイロン/還元/酸化処理を行った毛髪の常圧 DSC 曲線を示した.

未処理毛髮の常圧 DSC 測定では, 図に示されたように $230^{\circ} \mathrm{C}$ 付近に吸熱ピークを持つ曲線が得られる $[10,11]$. この $230^{\circ} \mathrm{C}$ 付近のピーク面積より $\alpha$-結晶の変性エンタル ピー $(\Delta \mathrm{H})$ が得られるが, その值は一連の処理を 1 回行う ことで $1.5 \mathrm{~J} / \mathrm{g}$ 減少し, 3 回繰り返し処理した毛髪では $3.5 \mathrm{~J} / \mathrm{g}$ 減少した. 蛍光顕微鏡観察では, 主な還元域はキューティ クル細胞であったが, 一連の熱アイロン/還元/酸化処理は コルテックス細胞にも影響をおよぼすことは明らかであ る.

しかし, 現在美容室で行われているストレートパーマ [還元 (10 分)/水洗/乾燥/熱アイロン $\left(180^{\circ} \mathrm{C}\right) /$ 酸化 $(10$ 分 $\left.)\right]$ 法で処理した毛髪での $\alpha$-結晶の $\Delta \mathrm{H}$ 変化(結果は省略し

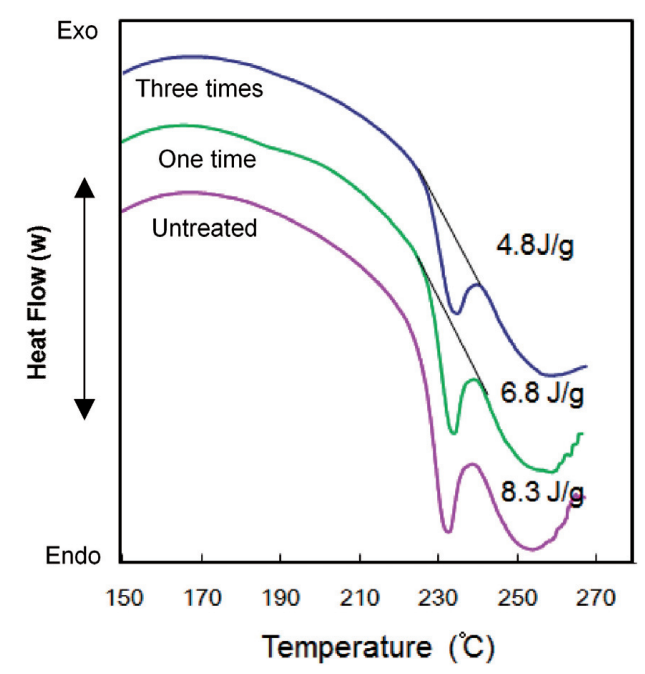

Fig. 6 Atmospheric pressure DSC thermographs for human hairs operated a predetermined number of times with iron straightening/reduction/oxidation/ hot iron drying processing.
た)が, 1 回処理で $4.8 \mathrm{~J} / \mathrm{g}, 3$ 回処理で $6.3 \mathrm{~J} / \mathrm{g}$ 減少しており, 明らかに熱アイロン/還元/酸化処理の方が従来法に比べコ ルテックス細胞におよぼす影響は小さいことがわかる.

ところで，別報 $[11,12]$ で報告したように， $\alpha$-結晶から なる IF 周辺域の-SS-結合が還元あるいは酸化処理により 切断された場合においても $\alpha$-結晶そのものは変性してい ない. また, 常圧 DSC 測定での $\alpha$-結晶変性ピーク温度お よびピーク面積が IF 周辺域に不揮発化合物が吸着するこ とによって変化することは既に知られている $[13,14]$. 特 に, 前報 $[11]$ では, 従来法での還元/ $\mathrm{N}-$ エチルマレインイ ミド処理毛髪の常圧 DSC 測定によって $\alpha$-結晶変性ピーク 温度の低温化およびピーク面積の減少を見出しているが, その原因は処理に用いた還元剤および反応生成物である ジチジグルコール酸などの吸着によりものである推察し た.これらのことを総合すると, 図 6 に示された $\Delta \mathrm{H}$ の 減少は, 一連の処理に使用したクリーム剤の構成成分お よび反応生成物の一部が IF 周辺域 [IF/IFAP]間に浸透吸着 したことによると考えられる.

すなわち，新規法である熱アイロン/還元/酸化処理では， コルテックス細胞内の-SS-結合の切断はほとんど起こらな いが, 使用したクリーム剤あるいは反応生成物の一部が コルテックス細胞内に浸透し, 施術を繰り返すことでコ ルテックス細胞の IF/IFAP 間に蓄積されるものと考えるこ とができる，なお，従来法では新規法に比べ $\Delta \mathrm{H}$ の減少 量が大きくなったが，これは IF/IFAP 間の-SS-結合が切断 され, その部分へのクリーム剤あるいは反応生成物の浸 透が容易となり, 繰り返し処理することによりその蓄積 量が多くなるためである考えられる.

\section{6 パーマネントセット形成における水素結合およ び-SS-結合の関わり}

以上のように，熱アイロンによりストレートセット(乾 燥状態)した後に還元・酸化処理する施術法によってスト レートパーマが得られたが, この現象を以下のように整 理することができる：

毛髪形状を変形セットするには, -SS-結合を切断する必 要はなく, 水素結合(やイオン結合)の切断よって動きが 容易となった分子鎖の再配列によって可能である. しか し, この毛髪の内部構造は不安定である. その原因は, セット時に切断されずに歪まされた-SS-結合とその-SS-結 合により架橋されている分子鎖に内在する歪が, セット 形状を元に戻す復元力と働くためである.この内部歪は, -SS-結合の切断とそれにともなう分子鎖の再配列によって 解消され, その結果, セット形状は安定化する.さらに, 日常のシャンプー等の湿潤時に生じる繊維内部膨潤圧に よって形状が変化するが, 酸化処理により再結合した-SS結合がその変化を抑制するように働く.

\section{4. 結 論}

本報告では, 一次セット挙動に着目し, あらかじめ熱 
アイロンによりストレートにセットしておいた毛髪の復 元力となる内部歪を, ストレート形状を維持したまま除 くことができれば，七ット形状が維持できるのではとの 考えに基づき検討を行ってきた. その結果, 内部歪の主 因子である歪んだ-SS-結合を還元処理により切断すること で湿潤耐性のあるセットが可能であることが見出だされ た.さらに，アイロン処理によるストレートセットにお いては, 毛髪構成分子の一部が再配列することが必要と なるが, その際, 構成分子鎖に歪が残存しない最適アイ ロン処理条件を選択することが重要であることも明らか になった.

また，還元により切断された-SS-結合の再結合はセット されたストレート形状に影響をおよぼさないことも明ら かになった.さらに, この一連の施術法によってセット した処理毛束を煮沸処理した後においてもストレート形 状が保たれていることから，本論文で報告した一連の施 術法によってウェーブ毛髪をパーマネント性に優れたス トレート状毛髪にセットできることが確認できた。

なお, 一次セット (乾燥状態)後に還元・酸化する本報 告の施術法は, ウェーブパーマにも応用できることが確 かめており (後日報告する予定である), この施術法が沉 用施術法として広く普及することを期待したい.

\section{文 献}

1. C. Bouillon, and J. Wilkinson "The Science of Hair Care"
Second ed., Taylor \& Francis, p215-218 (2005).

2. S. Ogawa, K. Fujii, K. Kanayama, K.Arai, and K.Joko, J. Cosmet. Sci., 51, 379-399 (2000).

3. H. Bogaty, J. Soc. Cosmetic Chemists, 11, 333-342 (1960).

4. K. Sakurai, and K. Joko, Sen'i Gakkaishi, 66, 272-279 (2010).

5. K. Joko, K. Sakurai, and Y Morimoto, Sen'i Gakkaishi, 69, 8-12 (2013).

6. K. Joko, and K. Sakurai, Sen 'i Gakkaishi, 69, 19-25 (2013).

7. C. R. Robbins, "Chemical and Physical Behavior of Human Hair", $5^{\text {th }}$ ed., New York, Springer-Verlag, p234236 (2013).

8. S. Ogawa, K. Fujii, K. Kanayama, and K. Arai, Sen'i Gakkaishi, 64, 137-144 (2008).

9. J. A. Swift, J. Cosmet. Sci., 50, 23-48 (1999).

10. F. J. Wortmann, and H. Dentz, J. Appl. Polym. Sci., 48, 137-150 (1993).

11. K. Joko, H. Takahashi, Y. Takeda, and A. Osaki, Sen'i Gakkaishi, 70, 152-159 (2014).

12. Osaki, M. Okada, K. Yamamoto, and K. Joko, J. Soc. Cosmet. Chem. Japan. 43, 86-94 (2009).

13. M. Hosokawa, M. Sato, and M. Sadai, J. Soc. Cosmet. Chem. Japan, 31, 167-175 (1997).

14. K. Joko, "Saishin no Mouhatsu Kagaku" Mouhatsu kagakusya kyokai, ed., Fragrance journal LTD., p194-195 (2003). 